\title{
Investigation and Discussion of Characteristics for Intermetallic Phases Common to Aluminum Alloys as a Function of Solution pH
}

\author{
N. Birbilis ${ }^{*, a, z}$ and R. G. Buchheit* \\ Fontana Corrosion Center, Department of Materials Science and Engineering, The Ohio State University, \\ Columbus, Ohio 43210, USA
}

This paper presents results for corrosion potentials, pitting potentials, and electrochemical characteristics for intermetallic particles commonly present in high strength aluminum-based alloys, for tests conducted in a $0.1 \mathrm{M} \mathrm{NaCl}$ solution of varying pH via the use of a microcapillary electrochemical cell. The intermetallics investigated were $\mathrm{Mg}_{2} \mathrm{Si}, \mathrm{MgZn}_{2}, \mathrm{Al}_{7} \mathrm{Cu}_{2} \mathrm{Fe}, \mathrm{Al}_{2} \mathrm{Cu}_{\mathrm{Al}} \mathrm{Al}_{2} \mathrm{CuMg}$, and $\mathrm{Al}_{3} \mathrm{Fe}$. Elaboration of the results reveals that the electrochemical behavior of such compounds varies markedly with $\mathrm{pH}$, with attendant ramifications for localized corrosion and protection in $\mathrm{Al}$ alloys. Examples of this are shown for AA7075-T651, where it is shown that the localized corrosion morphology is drastically different upon the bulk alloy depending on the $\mathrm{pH}$ of the test environment. A stochastic pitting is observed at an acid $\mathrm{pH}$, near-neutral conditions result in a deterministic-type pitting, and a general corrosion is observed at an alkaline $\mathrm{pH}$

(C) 2008 The Electrochemical Society. [DOI: 10.1149/1.2829897] All rights reserved.

Manuscript submitted October 2, 2007; revised manuscript received November 16, 2007

Available electronically January 22, 2008

In a recent review, we presented the electrochemical characteristics for a number of intermetallic particles and phases common to a large range of engineering aluminum (Al) alloys. ${ }^{1}$ In that case, the results were presented in a survey format as a function of chloride concentration in near-neutral solution.

In the case of "real" corrosion of Al alloys, not only will the environments to which they are exposed vary in $\mathrm{pH}$ (viz., acid rain, concentrated solution in aircraft lap joints, etc.), but gradients will also exist, often sharp, of $\mathrm{pH}$ across the alloy surface. ${ }^{2,3}$ As ought to be expected, the electrochemical response and activity of most metals and alloys will vary rather markedly with the solution $\mathrm{pH}^{4}{ }^{4}$ This will have attendant ramifications in the evolution and rate, and possibly the morphology, of the corrosion that develops on bulk Al alloys that contain phases and intermetallics of different composition (and hence electrochemical properties).

In the case of $\mathrm{Al}$ alloys in near-neutral bulk solutions, it is well established that pitting is influenced by intermetallic particles that exhibit different surface film characteristics to the matrix, and may be either anodic or cathodic relative to the matrix..$^{1-3,5-9}$ In such cases, two main types of pit morphologies are observed. So-called "circumferential" pits appear as a ring of attack around a more or less intact particle or particle colony, with the attack appearing to be mainly in the matrix phase (often termed "trenching", $, 3,10$ ). The second morphology is the apparent selective dissolution of an intermetallic particle. Pits of this type can be deep and may contain remnants of the particle in them. ${ }^{3}$ In contrast, comparatively little is known about bulk alloy corrosion morphology across the $\mathrm{pH}$ range.

The microstructures developed in high strength aluminum alloys are complex and incorporate a combination of equilibrium and nonequilibrium phases. In this study, we focused on the electrochemical properties of the synthesized intermetallics $\mathrm{MgZn}_{2}, \mathrm{Al}_{7} \mathrm{Cu}_{2} \mathrm{Fe}$, $\mathrm{Al}_{2} \mathrm{CuMg}, \mathrm{Al}_{2} \mathrm{Cu}, \mathrm{Mg}_{2} \mathrm{Si}$, and $\mathrm{Al}_{3} \mathrm{Fe}$, which have been quantitatively noted as being prominent in 7 xxx series alloys. ${ }^{11-14}$ This facilitates a focused discussion of the results in a practical context; however, it is emphasized that a number of the above-mentioned intermetallics can be found in several other common cast or wrought alloys (e.g., 2024, 6061). ${ }^{2,5,10,11,15}$ The aim of this work is to contribute to a detailed characterization of the electrochemical behavior of the intermetallic compounds in $\mathrm{Al}$ alloys, presenting previously unreported information, while attempting to provide a more quantitative description of mechanistic aspects of corrosion phenomena in

\footnotetext{
* Electrochemical Society Active Member.

a Present address: Department of Materials Engineering, Monash University, Vic. 3800, Australia.

zE-mail: birbilis.1@osu.edu
}

commercial $\mathrm{Al}$ alloys by determining reaction kinetics phase-byphase and upon well-defined particle types. It may be considered supplementary or additional to the work given in Ref. 1, while it can also be interpreted in the context of development of predictive models.

\section{Experimental}

Materials andmaterials characterization.- Electrochemical testing of intermetallic compounds synthesized in bulk form is now relatively common in the study of localized corrosion phenomena (Ref. 1 and references therein). In this case intermetallic particles were synthesized by combining the necessary proportions of constituent pure metals (supplied by Alfa-Aesar), the methodology and approach of which were covered in detail in Ref. 1. Fabrication was carried out via either induction or arc melting. Subsequent identification of intermetallics was done via scanning electron microscopy (SEM) (Philips XL-30 FEG-ESEM) enabled with quantitative energy dispersive X-ray spectroscopy (EDXS) and the facility to generate backscattered electron Kikuchi patterns. In the present study, the microscopy was also carried out using the Philips XL-30.

Electrochemical characterization.- Electrochemical testing was carried out using a microcell method, as outlined previously in Ref. 1 and 16-18. In this method, the working electrode area is defined by the area of metal that comes into contact with the opening of a microcapillary filled with an electrolyte, while containing a smallwire counter electrode and an electrolytic contact with a saturated calomel reference electrode. There are several unique aspects of microcell testing (viz., the effect of capillary diameter, solution resistance (iR) effects, and current limitations) that we have covered in detail elsewhere ${ }^{19}$ and need to be considered in the execution of such testing. In cases where the bulk alloy was tested (AA7075T651 supplied by Alcoa), the electrode area was $1 \mathrm{~cm}^{2}$ and the testing was carried out using a conventional "flat cell" (PAR).

Potentiodynamic polarization was carried out at a scan rate of $0.01 \mathrm{~V} \mathrm{~s}^{-1}$ using an Autolab PGSTAT 100. The tests reported herein should also be considered to have been carried out in aerated conditions, because no special effort was made to exclude oxygen from the capillary or solution. Each test was repeated at least six times and the average values are reported herein. Measurements were performed in $0.1 \mathrm{M} \mathrm{NaCl}$ at $\mathrm{pH}=2.5,6,10$, and 12.5. Temperature is considered to be constant at $20^{\circ} \mathrm{C}$.

\section{Results and Discussion}

Potentiodynamic polarization response of intermetallic particles as a function of $\mathrm{pH}$.- - Figures 1-6 summarize the potentiodynamic polarization response of $\mathrm{Al}_{7} \mathrm{Cu}_{2} \mathrm{Fe}, \mathrm{Al}_{2} \mathrm{Cu}, \mathrm{Al}_{3} \mathrm{Fe}, \mathrm{MgZn}_{2}, \mathrm{Mg}_{2} \mathrm{Si}$, 


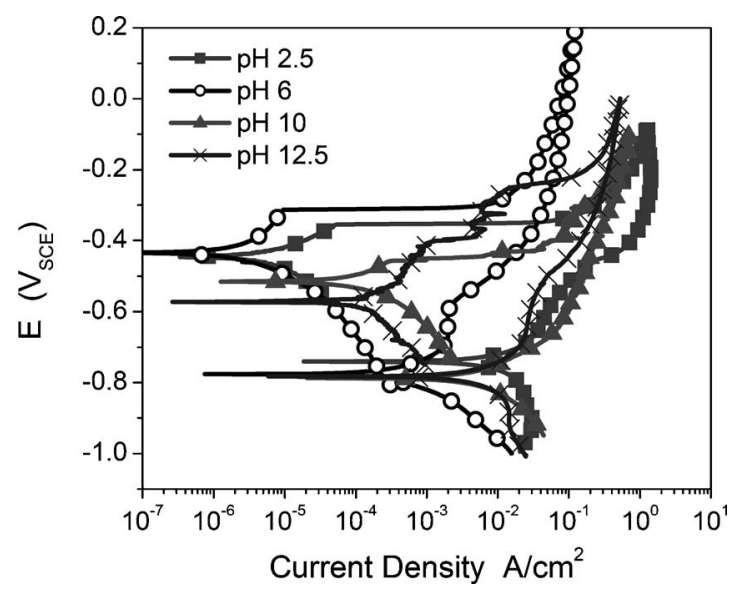

Figure 1. Potentiodynamic polarization diagrams for $\mathrm{Al}_{7} \mathrm{Cu}_{2} \mathrm{Fe}$ collected in $0.1 \mathrm{M} \mathrm{NaCl}$ at $\mathrm{pH} 2.5,6,10$, and 12.5 .

and $\mathrm{Al}_{2} \mathrm{CuMg}$ as a function of $\mathrm{pH}$. The reported values for both $E_{\text {corr }}$ and $E_{\text {pit }}$ nominally varied within a window; however, a representative polarization curve at each $\mathrm{pH}$ value is seen (in Fig. 1-6) from a group of at least six replicates. The distribution in the measured $E_{\text {corr }}$ and $E_{\text {pit }}$ is reported in Fig. 7-12. A more detailed discussion of these results is given in the following section.

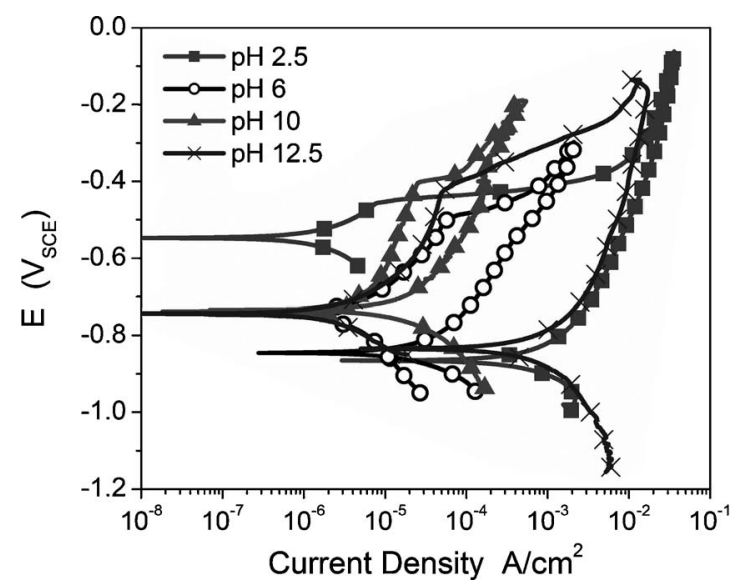

Figure 2. Potentiodynamic polarization diagrams for $\mathrm{Al}_{2} \mathrm{Cu}$ collected in 0.1 $\mathrm{M} \mathrm{NaCl}$ at $\mathrm{pH} 2.5,6,10$, and 12.5 .

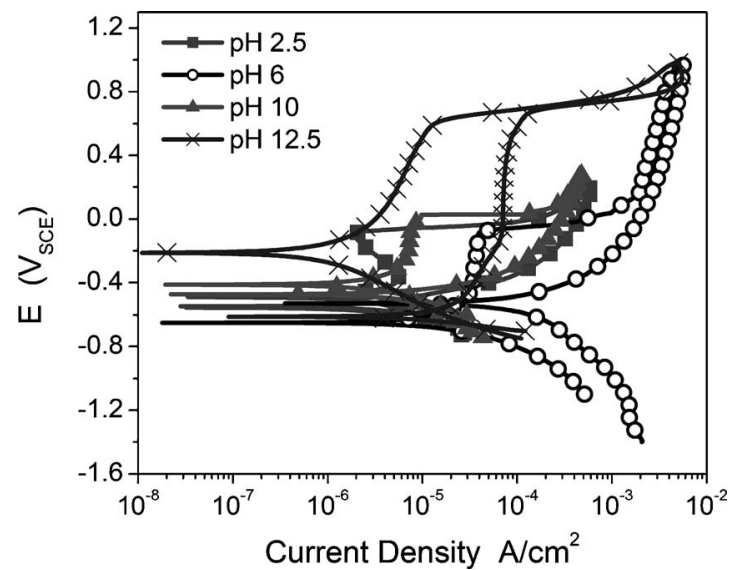

Figure 3. Potentiodynamic polarization diagrams for $\mathrm{Al}_{3} \mathrm{Fe}$ collected in 0.1 $\mathrm{M} \mathrm{NaCl}$ at $\mathrm{pH} 2.5,6,10$, and 12.5 .

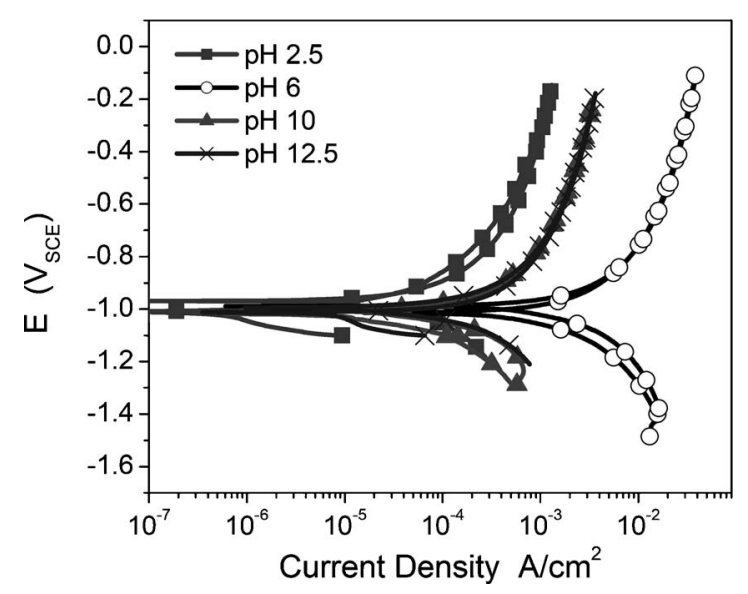

Figure 4. Potentiodynamic polarization diagrams for $\mathrm{MgZn}_{2}$ collected in 0.1 $\mathrm{M} \mathrm{NaCl}$ at $\mathrm{pH} 2.5,6,10$, and 12.5 .

$\mathrm{Al}_{7} \mathrm{Cu}_{2} \mathrm{Fe}$.- Figure 1 indicates that $\mathrm{Al}_{7} \mathrm{Cu}_{2} \mathrm{Fe}$ reveals a characteristic value for $E_{\text {pit }}$ over the range of $\mathrm{pH}$ values investigated. This indicates that over the range of $\mathrm{pH} 2.5-6$ this compound is "spontaneously passive" and does not freely corrode in a $0.1 \mathrm{M} \mathrm{NaCl}$ solution. The term spontaneously passive refers to a condition whereby (anodic) polarization above $E_{\text {corr }}$ reveals a typical passive region. We observe that $\mathrm{Al}_{7} \mathrm{Cu}_{2} \mathrm{Fe}$ displays a clear "breakdown"

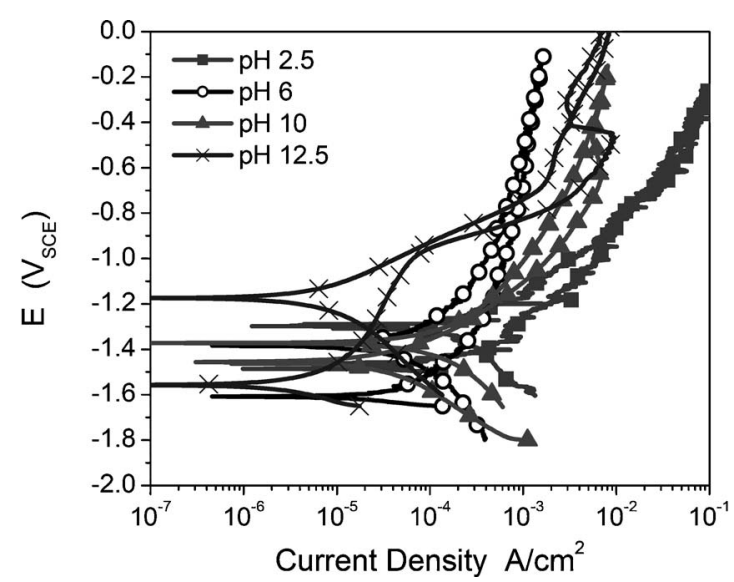

Figure 5. Potentiodynamic polarization diagrams for $\mathrm{Mg}_{2} \mathrm{Si}$ collected in 0.1 $\mathrm{M} \mathrm{NaCl}$ at $\mathrm{pH} 2.5,6,10$, and 12.5 .

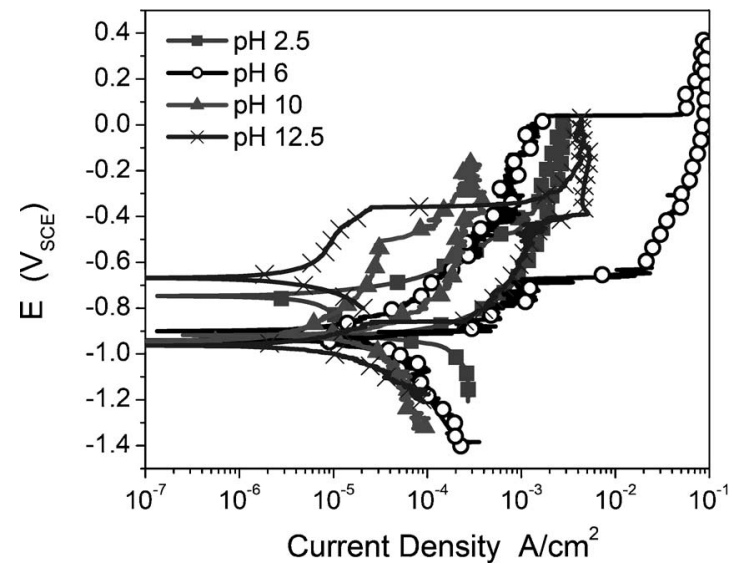

Figure 6. Potentiodynamic polarization diagrams for $\mathrm{Al}_{2} \mathrm{CuMg}$ collected in $0.1 \mathrm{M} \mathrm{NaCl}$ at $\mathrm{pH} 2.5,6,10$, and 12.5 . 


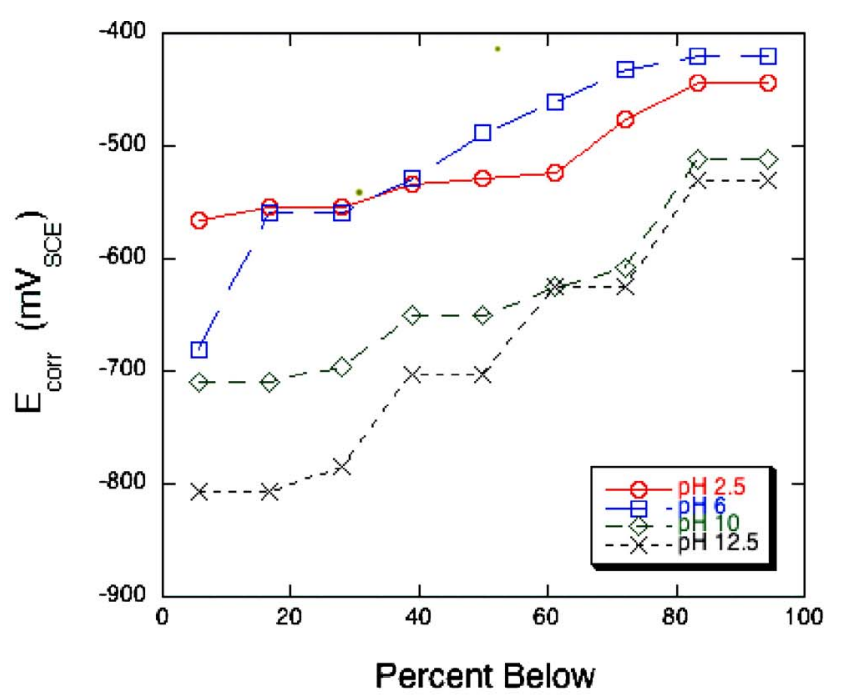

(a)

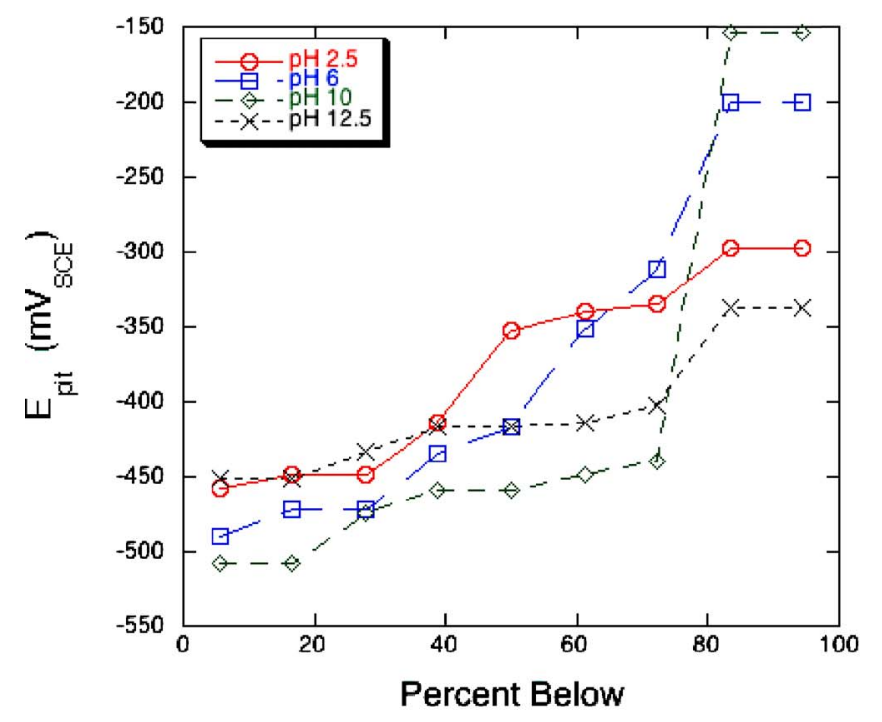

(b)

Figure 7. (Color online) Distribution plots of (a) $E_{\text {corr }}$ and (b) $E_{\text {pit }}$ for

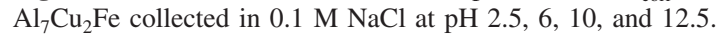

process and hence a distinct $E_{\text {pit }}$ value also. In the case of $\mathrm{pH} 10$ and 12.5 , however, we note that prior to breakdown, anodic current values are nominally high in the vicinity of $100 \mu \mathrm{A} / \mathrm{cm}^{2}$. This is also concomitant with the nominally high self-dissolution rate (i.e., the $i$ at $\left.E_{\text {corr }}\right)$. This phenomenon and its likely origin is explained somewhat further in the ensuing discussion, while cathodic polarization data are also given. An apparent trend in the results obtained for this compound is evident, whereby overall the value for $E_{\text {corr }}$ nominally decreases with increasing the $\mathrm{pH}$; however, the $E_{\text {pit }}$ values slightly increase with the $\mathrm{pH}$ as seen in Fig. 7. We also note from Fig. 1 that the repassivation potential for $\mathrm{Al}_{7} \mathrm{Cu}_{2} \mathrm{Fe}$ is $\mathrm{pH}$ independent and comparatively low at $\sim-800 \mathrm{mV}_{\mathrm{SCE}}$.

$\mathrm{Al}_{2} \mathrm{Cu}$.- Figure 2 shows the electrochemical response of $\mathrm{Al}_{2} \mathrm{Cu}$, revealing again that this compound is spontaneously passive and does not freely corrode in $\mathrm{NaCl}$ solution over the range of $\mathrm{pH}$ tested (2.5-12). At the lowest $\mathrm{pH}$ (most acid), the $E_{\text {corr }}$ value is some 200 $\mathrm{mV}$ more positive than the values observed at higher $\mathrm{pH}$ (alkaline), which is noteworthy. The results for testing at a $\mathrm{pH} 6,10$, and 12.5 are similar in their nature in that $\mathrm{Al}_{2} \mathrm{Cu}$ reveals a well-defined window of passivity for potentials broadly between about -700 and $-400 \mathrm{mV}_{\mathrm{SCE}}$. Figure $8 \mathrm{~b}$ reveals a marked increase in the $E_{\mathrm{pit}}$ of

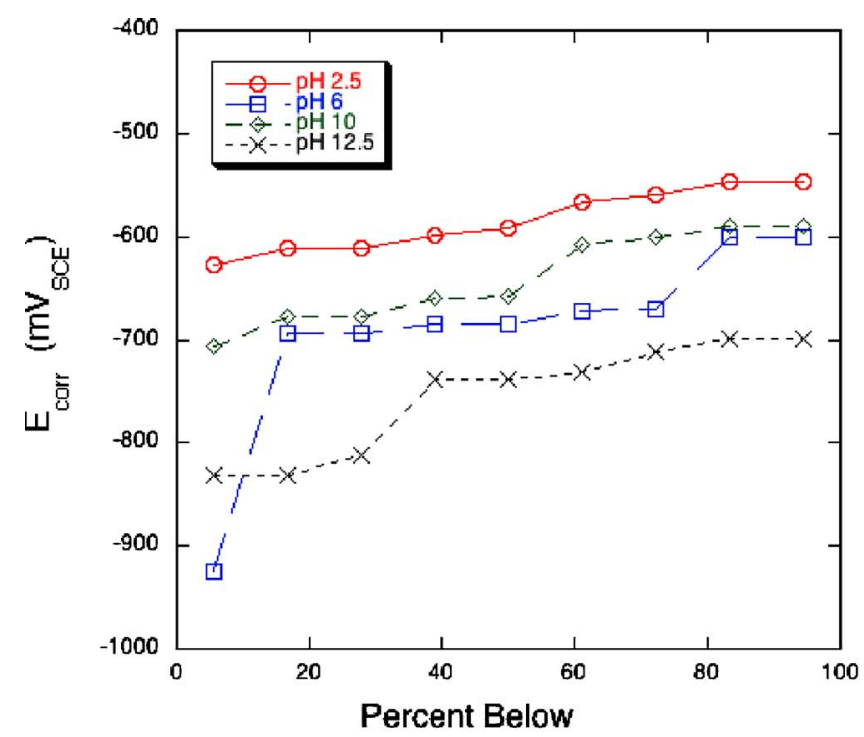

(a)

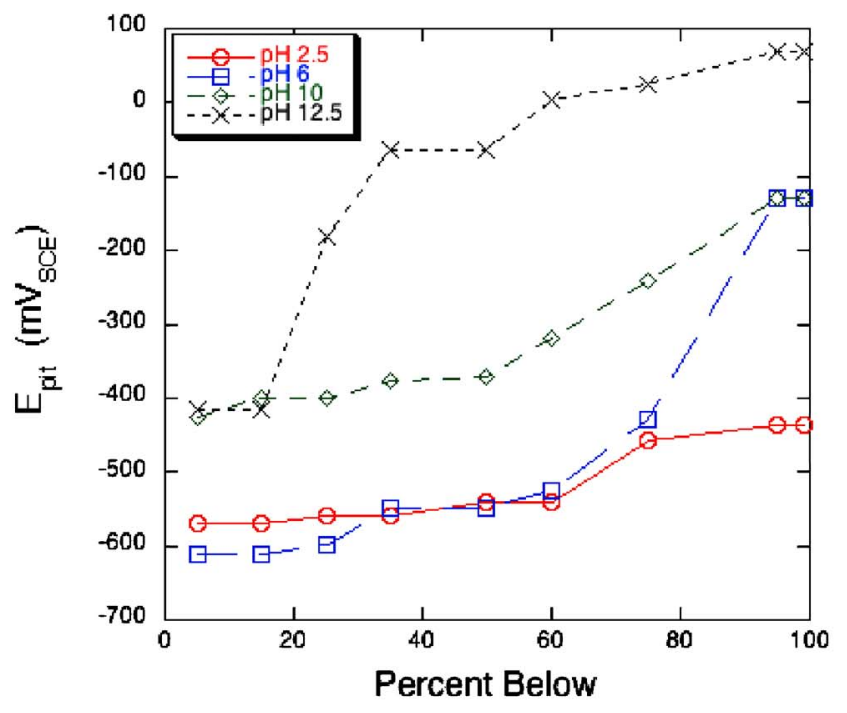

(b)

Figure 8. (Color online) Distribution plots of (a) $E_{\text {corr }}$ and (b) $E_{\text {pit }}$ for $\mathrm{Al}_{2} \mathrm{Cu}$ collected in $0.1 \mathrm{M} \mathrm{NaCl}$ at $\mathrm{pH} 2.5,6,10$, and 12.5 .

$\mathrm{Al}_{2} \mathrm{Cu}$ in an alkaline pH. Again, we can note from Fig. 2 that the repassivation potential of $\mathrm{Al}_{2} \mathrm{Cu}$ is $\mathrm{pH}$ independent and confined to a value in the vicinity of $\sim-900 \mathrm{mV}_{\mathrm{SCE}}$.

$\mathrm{Al}_{3} \mathrm{Fe}$.- Figure 3 also shows that $\mathrm{Al}_{3} \mathrm{Fe}$ displays well-defined regions of passivity prior to breakdown, with an attendant low selfdissolution rate. With the exception of testing at the highest $\mathrm{pH}$, the response of the compound is nominally similar, with an average passive window (viz., $E_{\text {corr }}-E_{\text {pit }}$ ) of about $400 \mathrm{mV}$. However, the passive current density at a $\mathrm{pH} 6$ is nominally about a factor of 5 greater than that at a $\mathrm{pH} 2.5$ or 10 (Fig. 3). Upon increasing the $\mathrm{pH}$ we concomitantly observe a disproportionate widening of the passive range to values in the vicinity of half a volt (apparent in Fig. $9 b)$, indicating an apparent thermodynamic stability in the environment tested and at an elevated $\mathrm{pH}$. This strong $\mathrm{pH}$ effect is probably due to the insolubility of $\mathrm{Fe}$ oxides under increasingly alkaline oxidizing conditions. We note that the behavior of $\mathrm{Al}_{3} \mathrm{Fe}$ varied markedly from that of $\mathrm{Al}_{7} \mathrm{Cu}_{2} \mathrm{Fe}$, which also contains $\mathrm{Cu}$.

$\mathrm{MgZn}_{2}$. - In the case of $\mathrm{MgZn}_{2}$, as seen in Fig. 4, we observe a general response that does not reveal any passivity; hence, corrosion occurs freely above the respective $E_{\text {corr }}$. In such cases, the corrosion 


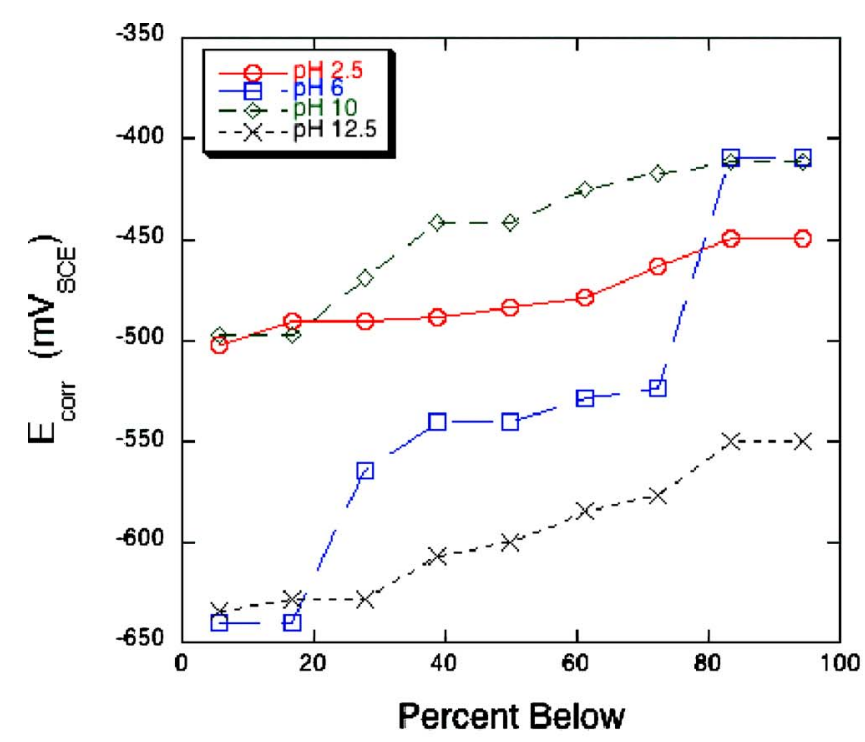

(a)

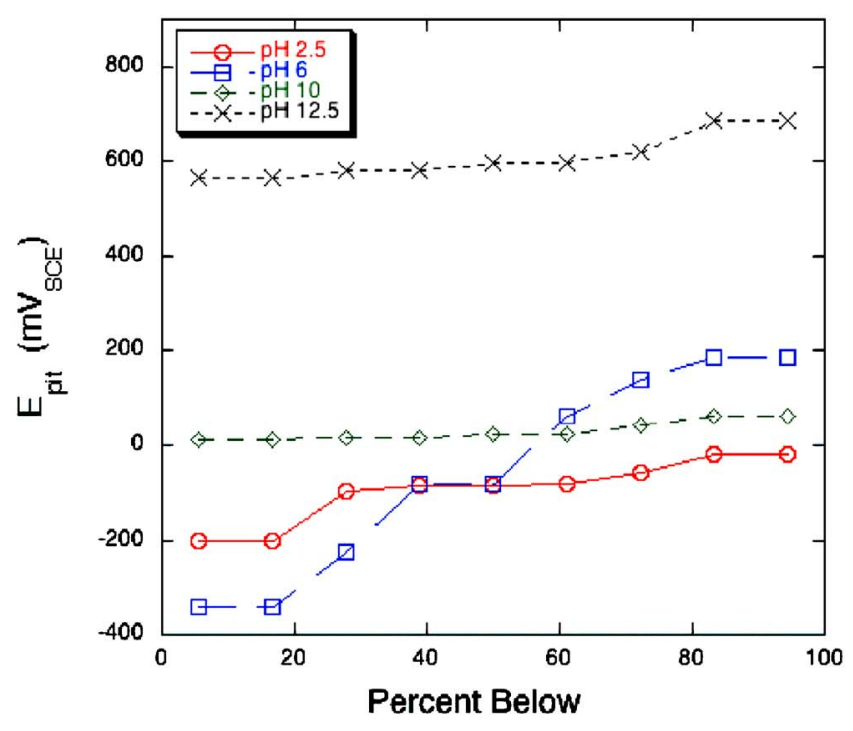

(b)

Figure 9. (Color online) Distribution plots of (a) $E_{\text {corr }}$ and (b) $E_{\text {pit }}$ for $\mathrm{Al}_{3} \mathrm{Fe}$ collected in $0.1 \mathrm{M} \mathrm{NaCl}$ at $\mathrm{pH} 2.5,6,10$, and 12.5 .

current gradually increases as potentials more anodic than $E_{\text {corr }}$ are realized. The currents sustained by $\mathrm{MgZn}_{2}$ at potentials separated from $E_{\text {corr }}$ by more than about $50 \mathrm{mV}$ are comparatively large, realizing several hundreds of $\mu \mathrm{A} / \mathrm{cm}^{2}$. Figure 10 reveals that, across the range of $\mathrm{pH}$ tested, the $E_{\text {corr }}$ of $\mathrm{MgZn}_{2}$ is nominally confined between -1000 and $-1050 \mathrm{mV}_{\mathrm{SCE}}$. This insensitivity to $\mathrm{pH}$ is unique among the phases presented herein. While $\mathrm{Mg}(\mathrm{OH})_{2}$ solubility is low at an elevated $\mathrm{pH}$, the results here tend to support that, into the range of alkaline $\mathrm{pH}$, the electrochemical response of $\mathrm{MgZn}_{2}$ appears to be dominated by the electrochemical behavior of $\mathrm{Zn}$.

$\mathrm{Mg}_{2} \mathrm{Si}$.- Figure 5 reveals the response of $\mathrm{Mg}_{2} \mathrm{Si}$. In an acidic solution, concomitant with the most noble $E_{\text {corr }}$ (Fig. 11a), $\mathrm{Mg}_{2} \mathrm{Si}$ shows high rates of dissolution with no evidence of passivity and dissolution rates of tens of $\mathrm{mA} / \mathrm{cm}^{2}$ for potentials greater than nominally about $-1.3 \mathrm{~V}_{\mathrm{SCE}}$. No apparent passivity or high rates of dissolution are also seen at $\mathrm{pH} 6$ and 9. However, in the case of $\mathrm{pH} 12.5$, a very reproducible window of passivity is observed over a range of about half a volt from $E_{\text {corr }}$, prior to a breakdown process being observed.

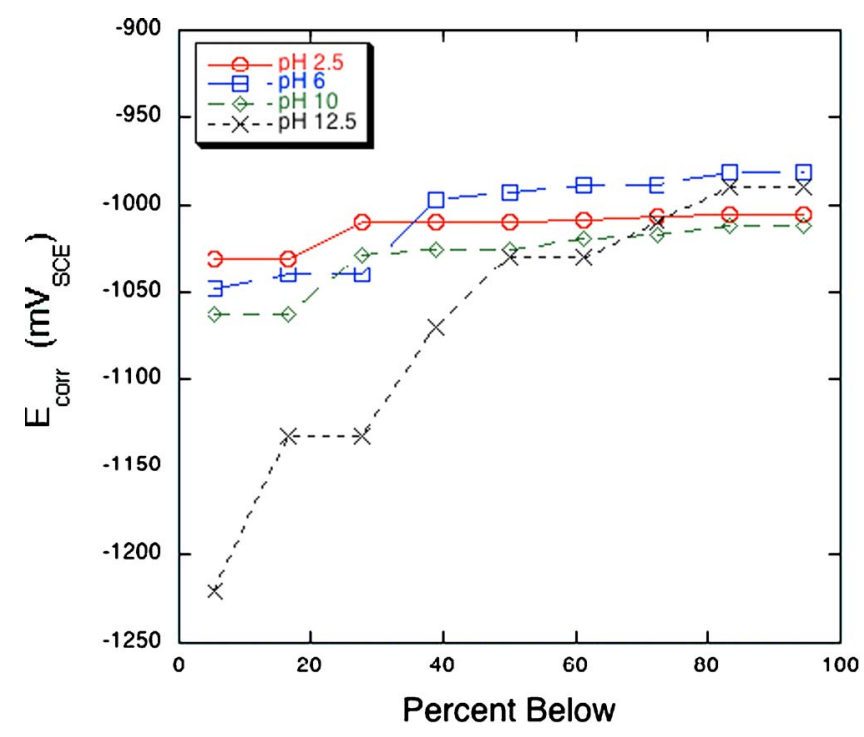

Figure 10. (Color online) Distribution plots of $E_{\text {corr }}$ for $\mathrm{MgZn}_{2}$ collected in $0.1 \mathrm{M} \mathrm{NaCl}$ at $\mathrm{pH} 2.5,6,10$, and 12.5 .

This phenomenon suggests that at such an elevated $\mathrm{pH} \mathrm{Mg}_{2} \mathrm{Si}$ is spontaneously passive, with an associated decrease in the dissolution rate by about two orders of magnitude over a wide range of potentials. The $E_{\text {pit }}$ at an elevated $\mathrm{pH}$ is reproducible within a welldefined window as seen in Fig. 11b. This passivity at an elevated $\mathrm{pH}$ is the likely result of $\mathrm{Mg}$ stability at an elevated $\mathrm{pH}$, suggesting the response of $\mathrm{Mg}_{2} \mathrm{Si}$ is dominated by $\mathrm{Mg}$. Figure 5 also reveals that the repassivation behavior varies as a function of the $\mathrm{pH}$, suggesting a selective incongruent dissolution of $\mathrm{Si}$ (discussed further below).

$\mathrm{Al}_{2} \mathrm{CuMg}$. - As previously noted, the electrochemical response of $S$-phase $\left(\mathrm{Al}_{2} \mathrm{CuMg}\right)$ is complex and often difficult to reproduce within a small error band, ${ }^{20,21}$ as also evidenced by Fig. 12. This is owing largely to the tendency of the compound to undergo a "dealloying" process that involves the selective dissolution of $\mathrm{Mg}$ and $\mathrm{Al}$, with the associated enrichment of $\mathrm{Cu}$ at the compound surface. The response of the compound (electrochemically) will therefore ultimately be heavily influenced by the $\mathrm{Cu}$-rich surface layer. The results in Fig. 6 indicate the typical electrochemical response observed in this testing. With the exception of the highest $\mathrm{pH}$ tested, $E_{\text {corr }}$ values were nominally in the general vicinity of about -850 to $-900 \mathrm{~V}_{\mathrm{SCE}}$. In the case of $\mathrm{pH} 2.5$ and 6 , what is nominally observed is an apparent range of passivity prior to a breakdown process. It is noted, however, that the current density corresponding with this range is rather high at $>100 \mu \mathrm{A} / \mathrm{cm}^{2}$, indicating that the system may not be "passive" at these potentials. This has been previously observed and it was hypothesized that the high current densities realized prior to the apparent breakdown are owing to the dealloying (i.e., a dissolution) process, with the ultimate observed breakdown corresponding to the activation of an essentially pure $\mathrm{Cu}$-rich surface layer. Further information regarding this hypothesis and its observation is not given in this paper; however, we do present the polarization curves as collected in order to convey the information herein as a survey of the results. As the $\mathrm{pH}$ increases, the apparent passive potential decreases to lower currents, suggesting that the activity of the compound decreases with $\mathrm{pH}$. At $\mathrm{pH} 12.5$, this is concomitant with an increase in $E_{\text {corr }}$ to more noble values, suggesting that the activity of the compound decreases with increasing the $\mathrm{pH}$. The repassivation potential is independent of the solution $\mathrm{pH}$.

In contrast to prior work, the net effect of increasing the $\mathrm{pH}$ is not as straightforward as we observed for increasing the $\mathrm{NaCl}$ concentration. ${ }^{1}$ In the case of $\mathrm{NaCl}$ variation, we nominally observed a decrease in $E_{\text {corr }}$ (to less noble values) concomitant with a 


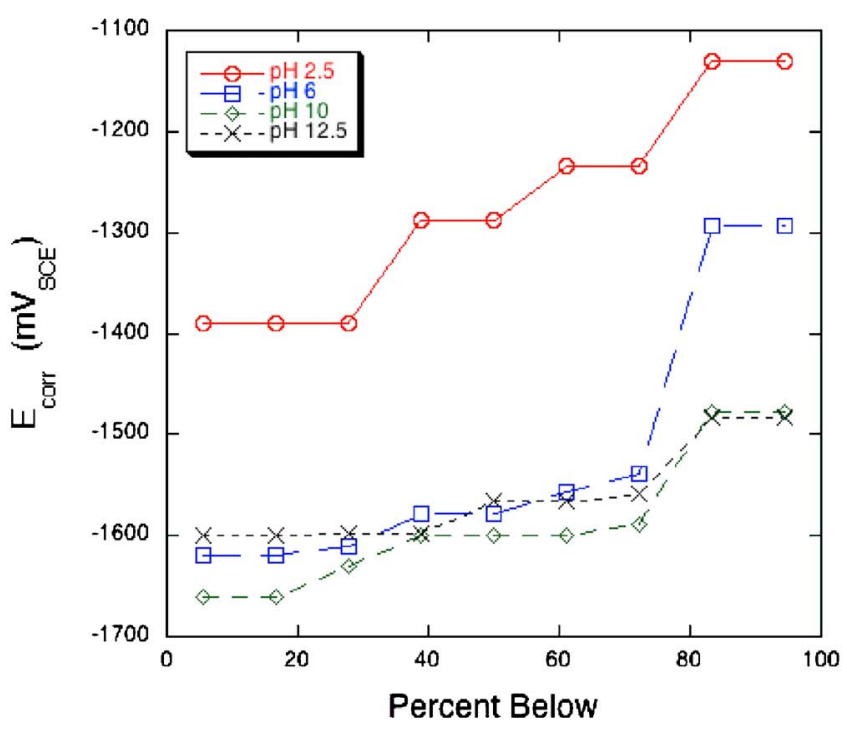

(a)

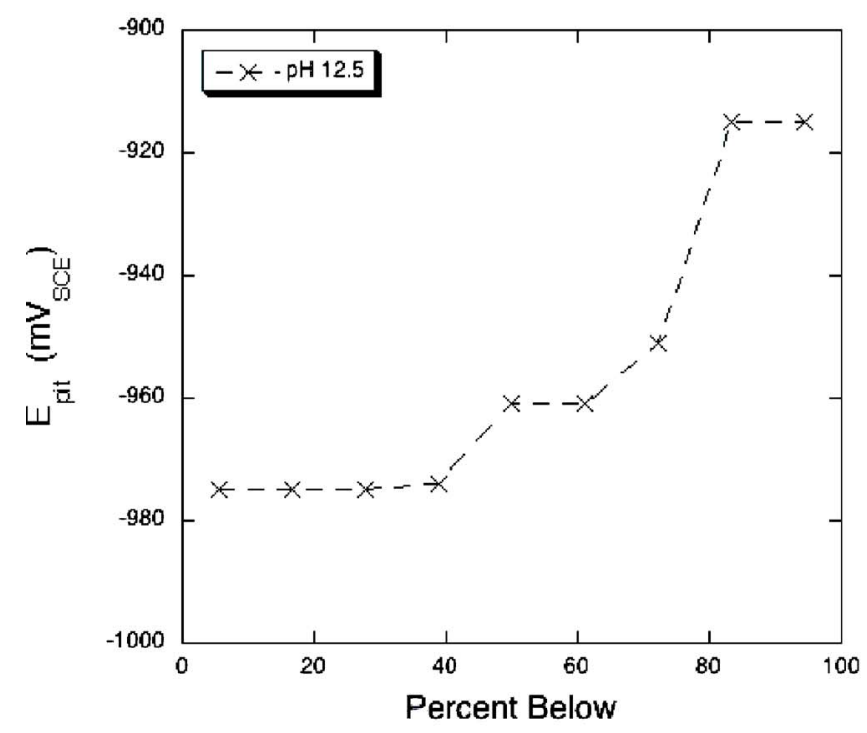

(b)

Figure 11. (Color online) Distribution plots of (a) $E_{\text {corr }}$ and (b) $E_{\text {pit }}$ for $\mathrm{Mg}_{2} \mathrm{Si}$ collected in $0.1 \mathrm{M} \mathrm{NaCl}$ at $\mathrm{pH} 2.5,6,10$, and 12.5.

decrease in $E_{\text {pit }}$ as the $\mathrm{NaCl}$ concentration was increased from 0.01 to $0.6 \mathrm{M}$. In the case of altering the $\mathrm{pH}$, the associated thermodynamics of each compound will vary depending on whether the solution is acidic, neutral, or basic; to an extent analogous to where the regions of stability may be found on a Pourbaix diagram. Consequently, not only is it difficult to predict the change in $E_{\text {corr }}$ of the compounds with environment, but the change in $E_{\text {corr }}$ reflecting thermodynamics will not intuitively correspond to the observed kinetics of the system in response to polarization. This is true for all the compounds tested here, reflecting the importance of polarization testing. We note and emphasize that there is a dispersion in the results presented in Fig. 1-6; therefore, the statistical distributions are given in Fig. 7-12. This serves to highlight that characteristic electrochemical parameters do vary within an envelope, while dispersion itself is a characteristic of intermetallic behavior.

Cathodic polarization response of intermetallic particles as a function of $\mathrm{pH}$.- In order to more specifically determine the electrochemical characteristics of intermetallics typically noted as being "cathodic" to the matrix of common aluminum alloys [broadly de-

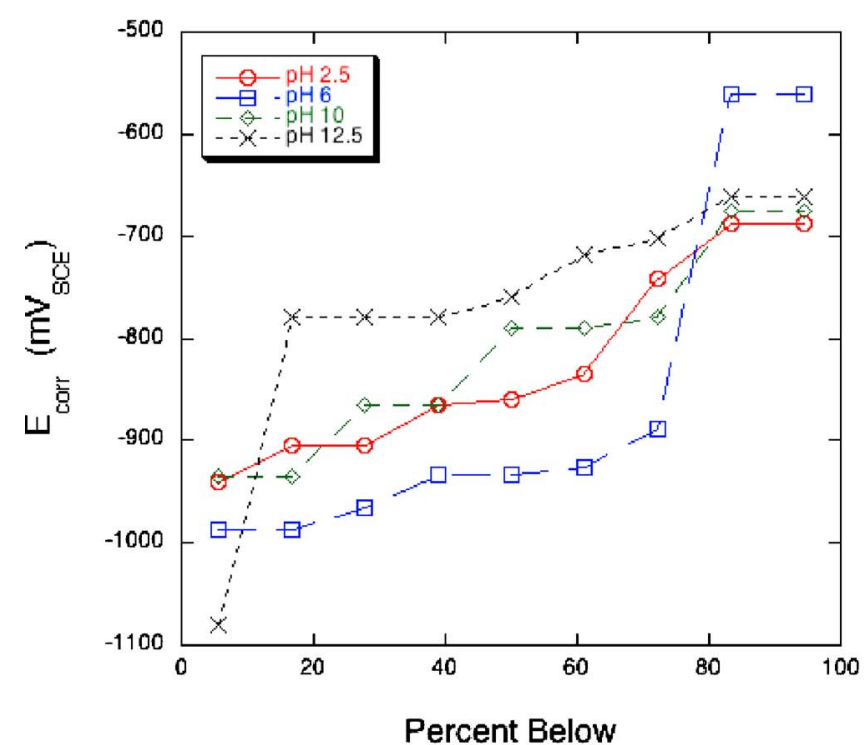

(a)

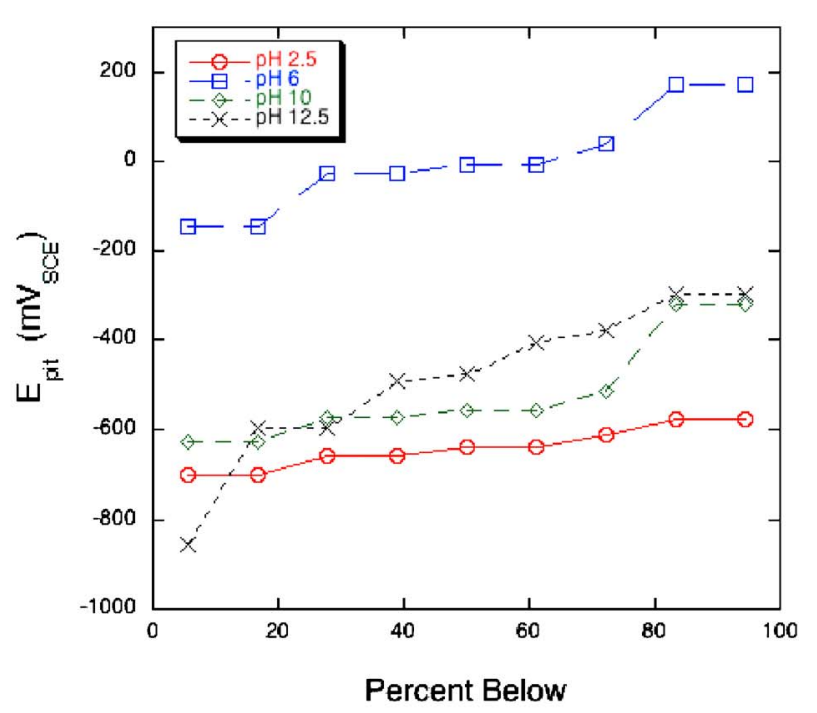

(b)

Figure 12. (Color online) Distribution plots of (a) $E_{\text {corr }}$ and (b) $E_{\text {pit }}$ for $\mathrm{Al}_{2} \mathrm{CuMg}$ collected in $0.1 \mathrm{M} \mathrm{NaCl}$ at $\mathrm{pH} 2.5,6,10$, and 12.5 .

fined as $E_{\text {corr }}$ (intermetallic) $>E_{\text {corr }}$ (alloy)], cathodic polarization curves were conducted upon $\mathrm{Al}_{7} \mathrm{Cu}_{2} \mathrm{Fe}, \mathrm{Al}_{2} \mathrm{Cu}$, and $\mathrm{Al}_{3} \mathrm{Fe}$, all of which nominally display an $E_{\text {corr }}$ more positive than $-700 \mathrm{mV}_{\mathrm{SCE}}$.

Figure 13 indicates the cathodic polarization characteristics of $\mathrm{Al}_{7} \mathrm{Cu}_{2} \mathrm{Fe}$, revealing that this compound is capable of sustaining relatively large cathodic current densities over the potential range tested. The response at $\mathrm{pH} 2.5$ and 6 is nominally very similar, with a mean $E_{\text {corr }}$ in the vicinity of $-550 \mathrm{mV}_{\mathrm{SCE}}$ and the ability to sustain cathodic currents in the range of several hundred $\mu \mathrm{A} / \mathrm{cm}^{2}$ at potentials $<-800 \mathrm{mV}_{\mathrm{SCE}}$. As the $\mathrm{pH}$ was increased, the $E_{\text {corr }}$ became more negative by about $100 \mathrm{mV}$, with a concomitant increase in the ability to sustain a cathodic current. Rates as high as several $\mathrm{mA} / \mathrm{cm}^{2}$ were typically observed over the potential range tested. This result may not have been predicted by analysis based on potential differences alone; however, the kinetics as determined from polarization testing shows enhanced rates of reaction, revealing $E_{\text {corr }}$ is not a satisfactory parameter to interpret, or even serve as a guide to, kinetics.

Figure 14 reveals the cathodic polarization response of $\mathrm{Al}_{2} \mathrm{Cu}$. 


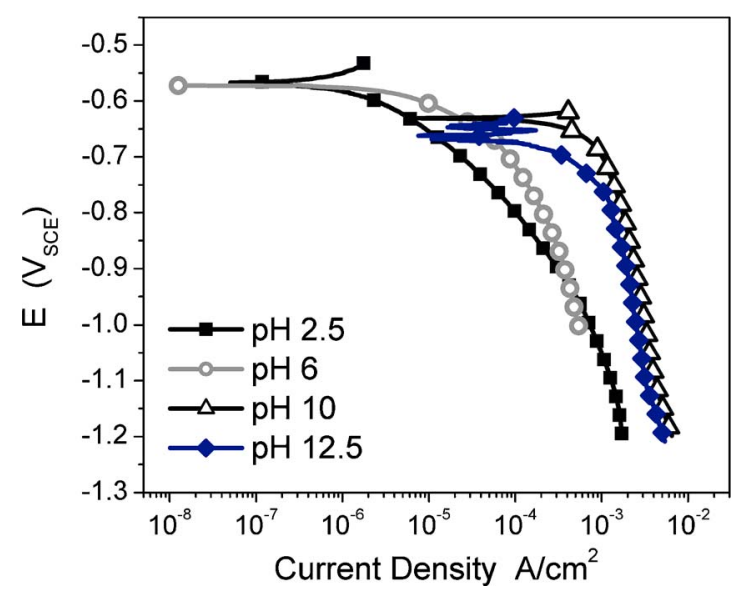

Figure 13. (Color online) Cathodic polarization diagrams for $\mathrm{Al}_{7} \mathrm{Cu}_{2} \mathrm{Fe}$ collected in $0.1 \mathrm{M} \mathrm{NaCl}$ at $\mathrm{pH} 2.5,6,10$, and 12.5 .

Within a rather well-defined band and neglecting variations in the $E_{\text {corr }}$ values, the cathodic response is rather similar for $\mathrm{Al}_{2} \mathrm{Cu}$ independent of the solution $\mathrm{pH}$. The values of the cathodic current are nominally somewhat below those of $\mathrm{Al}_{7} \mathrm{Cu}_{2} \mathrm{Fe}$ for similar potentials at $\mathrm{pH} 2.5$ and 6 , and significantly lower at basic $\mathrm{pH}$. These results correlate with those of Scully et al. ${ }^{7}$ for $\mathrm{Al}_{2} \mathrm{Cu}$, whereby $E_{\text {corr }}$ was found to decrease with increasing the $\mathrm{pH}$; however, in that case the testing was conducted in an inert $\left(\mathrm{Cl}^{-}\right.$-free) solution.

In Fig. 15 we see the cathodic polarization curves for $\mathrm{Al}_{3} \mathrm{Fe}$. Under acidic conditions, the cathodic current sustained is nominally about an order of magnitude lower than the values observed at a neutral or basic $\mathrm{pH}$. The response is very similar at $\mathrm{pH} 6,10$, and 12.5 over a wide range of potentials. With the exception of $\mathrm{pH} 2.5$, $\mathrm{Al}_{3} \mathrm{Fe}$ appears to sustain somewhat greater cathodic currents than $\mathrm{Al}_{2} \mathrm{Cu}$, but somewhat lower currents than $\mathrm{Al}_{7} \mathrm{Cu}_{2} \mathrm{Fe}$. Again, the electrochemical response of $\mathrm{Al}_{3} \mathrm{Fe}$ as determined herein was not necessarily obvious based on $E_{\text {corr }}$ measurements alone, as was previously reported, ${ }^{15}$ further highlighting the importance of the presentation of kinetic polarization data such as those given here.

Comments regarding electrochemical behavior of intermetallic particles as a function of $\mathrm{pH}$.- The observed differences in the electrochemical properties for the various compounds tested reflect the electrochemical heterogeneity that may be found in many commercial $\mathrm{Al}$ alloys. We note that the electrochemical response varies greatly depending on both the intermetallic composition and the solution $\mathrm{pH}$.

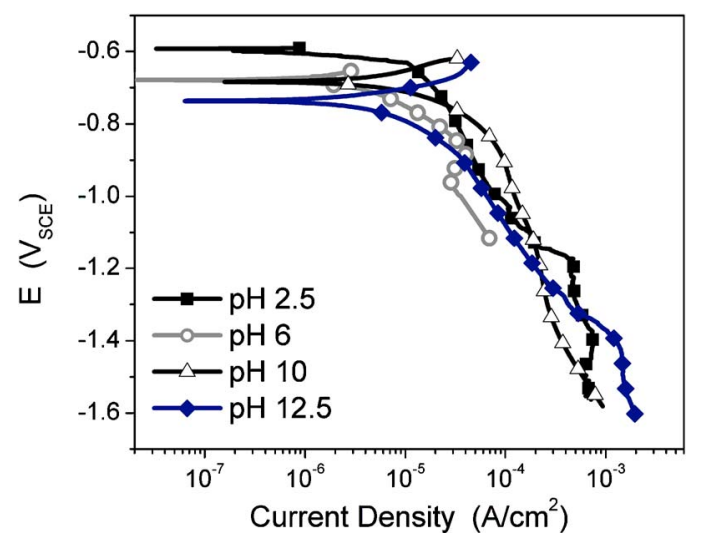

Figure 14. (Color online) Cathodic polarization diagrams for $\mathrm{Al}_{2} \mathrm{Cu}$ collected in $0.1 \mathrm{M} \mathrm{NaCl}$ at $\mathrm{pH} 2.5,6,10$, and 12.5 .

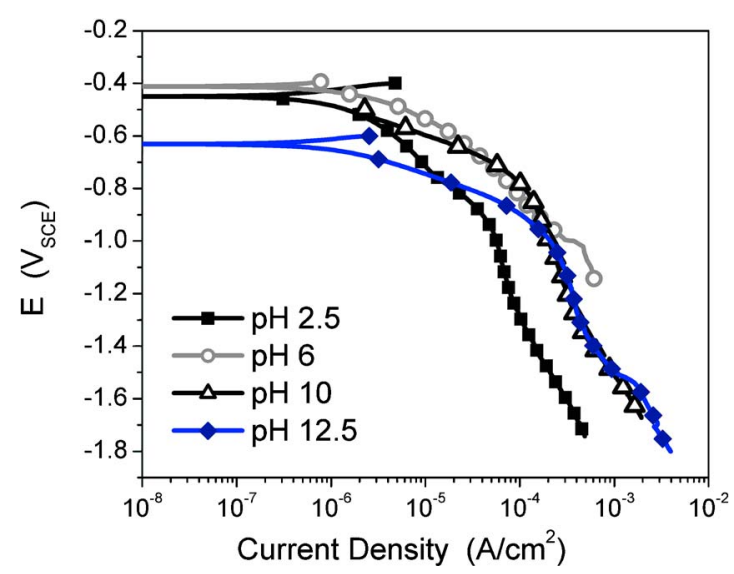

Figure 15. (Color online) Cathodic polarization diagrams for $\mathrm{Al}_{3} \mathrm{Fe}$ collected in $0.1 \mathrm{M} \mathrm{NaCl}$ at $\mathrm{pH} 2.5,6,10$, and 12.5 .

The results in Fig. 1-3 indicate that $\mathrm{Al}_{7} \mathrm{Cu}_{2} \mathrm{Fe}, \mathrm{Al}_{2} \mathrm{Cu}$, and $\mathrm{Al}_{3} \mathrm{Fe}$ reveal a characteristic breakdown potential, hence capable of maintaining some form of surface film, over the range of $\mathrm{pH}$ tested. This suggests that such compounds are stable in $\mathrm{NaCl}$ environments. It is noted that, as the $\mathrm{pH}$ increased, the cathodic current sustained increased in the case of $\mathrm{Al}_{7} \mathrm{Cu}_{2} \mathrm{Fe}$ and $\mathrm{Al}_{3} \mathrm{Fe}$. In the case of the former, the cathodic current density rapidly approached the $\mathrm{mA} / \mathrm{cm}^{2}$ range. In the context of localized corrosion of $\mathrm{Al}$ alloys in aerated conditions, this is significant. For example, if such cathodic intermetallics are the preferred sites for oxygen reduction, then the associated hydroxyl ion generation should cause a local $\mathrm{pH}$ increase (tending toward alkaline conditions) at the intermetallic surface for a nominally neutral $\mathrm{pH}$ bulk solution. In the case where cathodic efficiency increases with the $\mathrm{pH}$, such as the Fe-containing intermetallics, then their potency as local cathodes ought to increase as localized corrosion proceeds. The precise reason why the Fe-containing intermetallics increase in cathodic efficiency is not specifically studied here by way of surface analysis or chemistry, but is posited to be as the result of $\mathrm{Fe}$ stability at an elevated $\mathrm{pH}$. For example, $\mathrm{Al}_{7} \mathrm{Cu}_{2} \mathrm{Fe}$ compared to $\mathrm{Al}_{2} \mathrm{Cu}$ indicates a greater cathodic efficiency, linked to the presence of $\mathrm{Fe}$. Similarly, $\mathrm{Al}_{3} \mathrm{Fe}$ shows a greater cathodic efficiency than $\mathrm{Al}_{2} \mathrm{Cu}$.

The work herein has highlighted that $\mathrm{Al}_{7} \mathrm{Cu}_{2} \mathrm{Fe}, \mathrm{Al}_{3} \mathrm{Fe}$, and $\mathrm{Al}_{2} \mathrm{Cu}$ are all capable of functioning as potent local cathodes, owing to the appreciable cathodic currents sustained over a wide range of potentials typical of $\mathrm{Al}$ alloys ${ }^{2,12}$ across the $\mathrm{pH}$ range tested. The traditional belief is that the associated local cloud of alkaline $\mathrm{pH}$ that emanates from a cathodic particle (owing to hydroxyl ion generation from oxygen reduction) is principally responsible for corrosion of the adjacent matrix in near-neutral bulk solutions, because $\mathrm{Al}$ and its solid solutions nominally dissolve in alkaline conditions. ${ }^{22,23}$ Recent calculations and detailed examinations of peripheral pitting, however, ${ }^{3,5,15}$ indicated that it does not appear likely that the local alkalinity alone causes a significant peripheral dissolution. The details of such work are given in the respective papers, emphasizing that the dominant mechanism for peripheral pitting may be largely due to charge transfer, which, based on the work presented herein, could be possibly amplified by enhanced oxygen reduction kinetics upon the cathodic intermetallics themselves (as the local $\mathrm{pH}$ on the intermetallic surface increases) to support self-sustaining acidic corrosion pits. Evidence for anodic dissolution within the peripheral pits is provided by the hydrogen bubble evolution in direct observation studies of localized corrosion in $\mathrm{Al}$ alloys, ${ }^{24}$ suggesting that overall alloy corrosion, at least initially, proceeds almost selfcatalytically.

In contrast, $\mathrm{MgZn}_{2}$ did not reveal any stability or passive response over the range of $\mathrm{pH}$ tested, indicating that such a compound will ultimately undergo appreciable dissolution in the environments 


\begin{tabular}{|c|c|c|c|c|c|}
\hline Stoichiometry & Phase & $\mathrm{pH}$ & $E_{\text {corr }} \mathrm{mV}_{\mathrm{SCE}}{ }^{\mathrm{a}}$ & $E_{\text {pit }} \mathrm{mV}_{\mathrm{SCE}}^{\mathrm{a}}$ & $\begin{array}{l}\text { Current }\left(\mathrm{A} / \mathrm{cm}^{2}\right) \text { at } \\
\quad-900 \mathrm{mV}_{\mathrm{SCE}}{ }^{\mathrm{b}}\end{array}$ \\
\hline \multirow{3}{*}{$\mathrm{Al}_{3} \mathrm{Fe}$} & & 6 & -539 & 106 & $-1.6 \times 10^{-4}$ \\
\hline & & 10 & -408 & 40 & $-1.2 \times 10^{-4}$ \\
\hline & & 12.5 & -230 & 550 & $-1.1 \times 10^{-4}$ \\
\hline \multirow[t]{4}{*}{$\mathrm{Al}_{2} \mathrm{Cu}$} & $\theta$ & 2.5 & -546 & -458 & $-3.8 \times 10^{-5}$ \\
\hline & & 6 & -665 & -544 & $-4.1 \times 10^{-5}$ \\
\hline & & 10 & -739 & -408 & $-1.1 \times 10^{-4}$ \\
\hline & & 12.5 & -743 & -407 & $-3.8 \times 10^{-5}$ \\
\hline \multirow[t]{4}{*}{$\mathrm{MgZn}_{2}$} & $\mathrm{M}, \eta$ & 2.5 & -1007 & - & $1.2 \times 10^{-4}$ \\
\hline & & 6 & -1003 & - & $1.0 \times 10^{-3}$ \\
\hline & & 10 & -999 & - & $5.0 \times 10^{-4}$ \\
\hline & & 12.5 & -1012 & - & $4.8 \times 10^{-4}$ \\
\hline \multirow[t]{2}{*}{$\mathrm{Mg}_{2} \mathrm{Si}$} & $\beta$ & 2.5 & -1408 & - & $3.4 \times 10^{-3}$ \\
\hline & & 12.5 & -1553 & $-951^{\mathrm{c}}$ & $5.0 \times 10^{-5}$ \\
\hline \multirow[t]{4}{*}{$\mathrm{Al}_{7} \mathrm{Cu}_{2} \mathrm{Fe}$} & - & 2.5 & -535 & -451 & $-3.2 \times 10^{-4}$ \\
\hline & & 6 & -551 & -448 & $-4.2 \times 10^{-4}$ \\
\hline & & 10 & -604 & -420 & $-2.4 \times 10^{-3}$ \\
\hline & & 12.5 & -594 & -410 & $-2.6 \times 10^{-3}$ \\
\hline \multirow[t]{4}{*}{$\mathrm{Al}_{2} \mathrm{CuMg}$} & $\mathrm{S}$ & 2.5 & -750 & - & $-2.0 \times 10^{-5}$ \\
\hline & & 6 & -883 & $80^{\mathrm{d}}$ & $\pm 1 \times 10^{-5}$ \\
\hline & & 10 & -850 & $-390^{\mathrm{d}}$ & $\pm 1 \times 10^{-6}$ \\
\hline & & 12.5 & -670 & -350 & $-3.6 \times 10^{-5}$ \\
\hline \multicolumn{6}{|c|}{ Dispersion of these values seen in Fig. 7-12. } \\
\hline \multicolumn{6}{|c|}{ Average values reported. Results varied typically within $20 \%$ of the average. } \\
\hline \multicolumn{6}{|c|}{ Breakdown was only revealed for this compound for the highest $\mathrm{pH}$ tested $(\mathrm{pH} 12.5)$} \\
\hline \multicolumn{6}{|c|}{$\begin{array}{l}E_{\text {corr }} \text { of this compound is in the vicinity of }-900 \mathrm{mV}_{\mathrm{SCE}} \text {, making it difficult to yield an approximate average current because in cases it may be net anodic } \\
\text { or net cathodic; however, in all cases the current is low with an absolute value }<1 \times 10^{-5} \mathrm{~A} / \mathrm{cm}^{2} \text {. }\end{array}$} \\
\hline
\end{tabular}

tested and as a component of Al alloys, with microstructural evidence of this existing. ${ }^{13}$ This is significant because the $\mathrm{MgZn}_{2}$ is present in a large number density for $7 \mathrm{xxx}$ series $\mathrm{Al}$ alloys, ${ }^{13,25,26}$ and more specifically populates the grain-boundary regions.

The electrochemical response of $\mathrm{Mg}_{2} \mathrm{Si}$ reveals some interesting characteristics. Under acidic conditions, high dissolution rates are observed (viz., in the $\mathrm{mA} / \mathrm{cm}^{2}$ range). No evidence of passivity is observed at $\mathrm{pH} 6$ or 10; however, at $\mathrm{pH} 12.5$, the dissolution characteristics of $\mathrm{Mg}_{2} \mathrm{Si}$ are markedly different. There is a well-defined window of passivity that may be expected to be observed for pure $\mathrm{Mg}$ at elevated $(>11) \mathrm{pH}$. Consequently, for environments where the bulk solution is not heavily basic, significant self-dissolution of $\mathrm{Mg}_{2} \mathrm{Si}$ ought to be expected. Other recent work in our laboratory revealed that, during dissolution of $\mathrm{Mg}_{2} \mathrm{Si}$, there is an apparent incongruent dissolution, whereby the loss of $\mathrm{Mg}$ reveals remnant $\mathrm{Si}$ on the alloy surface, suggesting that $\mathrm{Mg}$ may dominate the electrochemical response of $\mathrm{Mg}_{2} \mathrm{Si}^{27}$

As previously suggested, the electrochemical behavior of $\mathrm{Al}_{2} \mathrm{CuMg}$ is complex and unique owing to the de-alloying processes. Unambiguous characterization of the precise kinetics and associated phenomenology of the electrochemical response ultimately requires an associated surface analysis and detailed analytical microscopy. ${ }^{21,28}$ However, for the purpose herein, the potentiodynamic results presented in Fig. 6 indicate that, as pH tends toward basic conditions, the attendant passive current density decreases remarkably to about $10 \mu \mathrm{A} / \mathrm{cm}^{2}$. This may indicate a reduction in the de-alloying processes. Again, this could be associated with the thermodynamic stability of $\mathrm{Mg}$ at an elevated $\mathrm{pH}$, and may also be influenced by the low electrochemical activity of $\mathrm{Cu}$ at an elevated $\mathrm{pH}^{4,5}$

The data presented herein may be incorporated into a discussion of the corrosion damage evolution in the context of a $7 \mathrm{xxx}$ series $\mathrm{Al}$ alloy. The $E_{\text {corr }}$ of most Al-Zn-Mg based alloys, is nominally in the vicinity of about $-900 \mathrm{mV}$ in a quiescent neutral $\mathrm{NaCl}$ solution. ${ }^{8,12,29}$ Information pertaining to the average currents measured upon compounds tested as a function of the $\mathrm{pH}$ at such a potential is included in Table I (along with mean $E_{\text {corr }}$ and $E_{\text {pit }}$ values). This information provides a deeper insight into the overall behavior of the alloy, further indicating the weaknesses of $E_{\text {corr }}$ values or potential gradients (i.e., the difference between the $E_{\text {corr }}$ of the particle and the matrix) alone as the basis for mechanistic interpretations of alloy corrosion. Similarly, this indicates the weakness of grouping together all particles as simply "anodic" or "cathodic", or only characterizing particles in a qualitative manner, which is often the case in prior works. Processes such as de-alloying, incongruent dissolution, a heavily $\mathrm{pH}$-dependent electrochemical response, and current sustaining ability (which has been shown to be unrelated to the value of $E_{\text {corr }}$ or even $E_{\text {pit }}$, which is commonly used as a measure of the relative nobility of intermetallics) need to be uniquely considered in understanding the extent, morphology, and rate of the corrosion damage. Such information may also be useful in the formulation of customized corrosion protection regimes, because certain aspects of the corrosion cycle, i.e., Fe-containing particles leading to peripheral pitting (Fig. 16), can be identified as key contributors to the corrosion cycle and be targeted by the appropriate inhibitors.

Behavior and corrosion morphology of AA7075-T651 as a function of bulk solution $\mathrm{pH}$.- The above discussion related largely to the localized corrosion in a near-neutral $\mathrm{pH}$ solution, where $\mathrm{pH}$ gradients can exist locally upon the alloy surface. This section, however, deals with varying the $\mathrm{pH}$ of the bulk solution. Thus specific tests were conducted on AA7075-T651 in order to reconcile the fundamental (microcell) electrochemical information collected and presented with damage evolution upon a bulk alloy, combining some results with the discussion. 


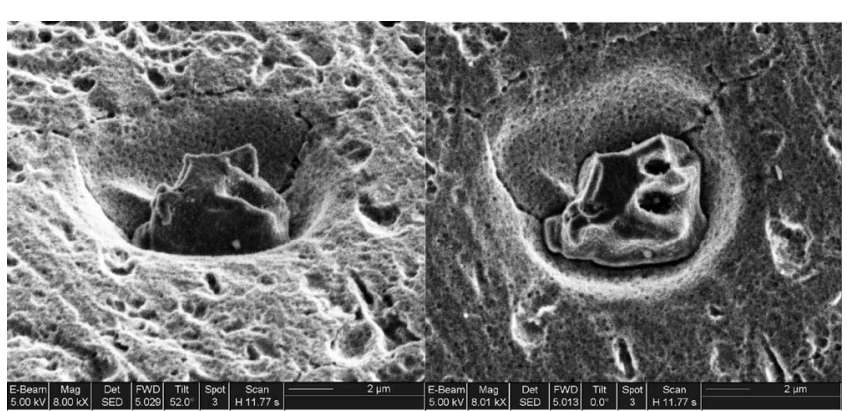

(a)

(b)

Figure 16. High-resolution SEM images revealing the corrosion morphology associated with an $\mathrm{Al}_{7} \mathrm{Cu}_{2} \mathrm{Fe}$ particle in AA7075-T651 immersed for 10 $\mathrm{h}$ in $0.1 \mathrm{M} \mathrm{NaCl}$ at $\mathrm{pH}$ 6. Images taken at (a) $52^{\circ}$ tilt, (b) $0^{\circ}$ tilt (secondary electron image).

Although an acid or alkaline bulk environment nominally represents unlikely extremes in the prescription of $\mathrm{Al}$ alloys, time or service conditions may conspire to produce such undesirable conditions. The examples herein will highlight that, in cases where the local electrolyte may tend to acid or alkaline conditions, the attendant damage morphology then will be different, while such exposures can complement the individual microcell results collected for specific intermetallics.

Figure 17 reveals the evolution of open-circuit potential (OCP) of AA7075-T651 for acid ( $\mathrm{pH} \mathrm{2.5),} \mathrm{near-neutral} \mathrm{(} \mathrm{pH}$ 6), and alkaline ( $\mathrm{pH}$ 12.5) conditions. We see that in acid conditions the alloy initially displays a comparatively noble OCP which decreases with time toward $\sim-900 \mathrm{mV}_{\mathrm{SCE}}$. For neutral conditions we see the welldocumented response that, following an initial transient period commencing at $\mathrm{OCP}<-1 \mathrm{~V}$, the potential varies within a narrow window close to $\sim-750 \mathrm{mV}_{\mathrm{SCE}}$. In the case of an alkaline solution, the OCP reveals a marked decrease, commencing at a comparatively very negative value of $\sim-1650 \mathrm{mV}_{\mathrm{SCE}}$, followed by an ennoblement with time.

The OCP testing suggests a markedly different electrochemical response for the bulk alloy with $\mathrm{pH}$, and this is seen clearly in Fig. 18 for potentiodynamic testing upon AA7075-T651. We see, at a near-neutral $\mathrm{pH}$, a very small window of passivity (i.e., $<100 \mathrm{mV}) .{ }^{26}$ This window is however time dependent and diminishes with continued immersion. ${ }^{26}$ However, at $\mathrm{pH} 2.5$, dissolution occurs at high rates for $E>E_{\text {corr }}$. Conversely, the self-dissolution rate for testing at $\mathrm{pH} 12.5$ is nominally nearly two orders of magnitude greater, and again no passivity is seen.

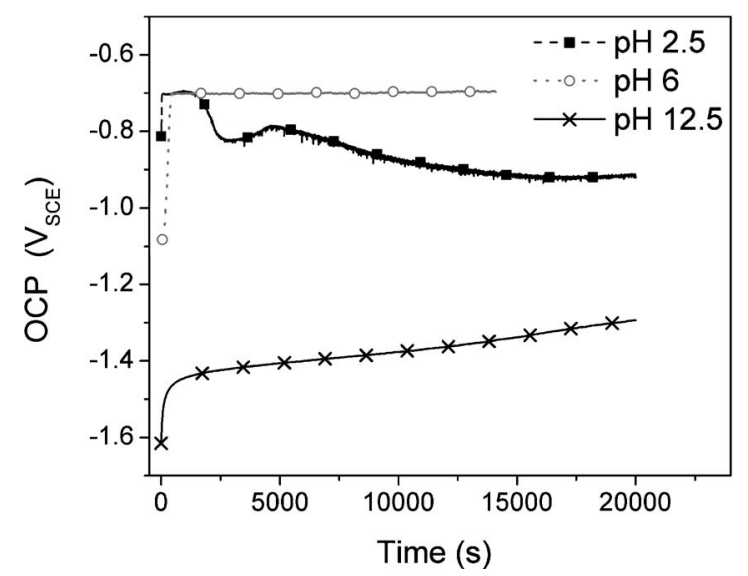

Figure 17. OCP vs time for AA7075-T651 collected in $0.1 \mathrm{M} \mathrm{NaCl}$ at $\mathrm{pH}$ $2.5,6$, and 12.5 .

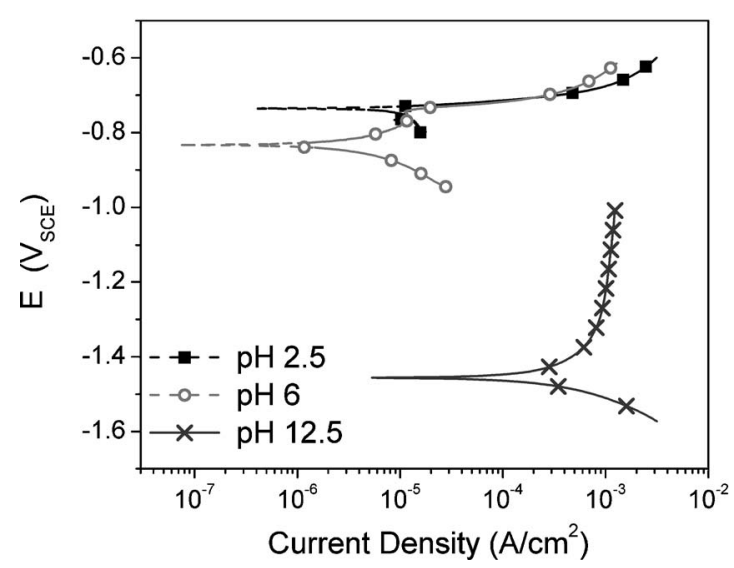

Figure 18. Potentiodynamic polarization diagrams for AA7075-T651 collected in $0.1 \mathrm{M} \mathrm{NaCl}$ at $\mathrm{pH} 2.5,6$, and 12.5 .

Figure 19 reveals the typical damage morphology, as determined by SEM, for AA7075-T651 in $0.1 \mathrm{M} \mathrm{NaCl}$ at pH 2.5 following $24 \mathrm{~h}$ immersion. A large-scale pitting is observed. These pits are in no way associated with cathodic particles (which are seen as light stringers in the SEM image of Fig. 19). What is seen is loss (i.e., dissolution) of "anodic" particles (viz., $\mathrm{Mg}_{2} \mathrm{Si}$ and $\mathrm{MgZn}_{2}$ ) as gauged by their lack of presence from navigating the sample. However, pitting is also randomly occurring, to a large extent, in the matrix at local sites, likely related to stochastic defects in the matrix oxide and in accordance with the thermodynamic instability of $\mathrm{Al}$ and its solid solutions in acid conditions. The determination of the corrosion morphology in Fig. 19 is important, as it highlights physically the thermodynamic stability of so-called "cathodic" particles, because they remain largely unaffected as the corrosion proceeds. Furthermore, particles such as $\mathrm{Mg}_{2} \mathrm{Si}$ and $\mathrm{MgZn}_{2}$, expected to be dissolved, show no evidence of existence, in accordance with the microcell test prediction.

A higher resolution image of the damage seen in an apparently unaffected area in Fig. 19 is seen in Fig. 20. In this case, a strong secondary electron contrast was used to reveal localized pitting patterns, such that they appear to reveal a "mesh" or network of damage (see the darkest regions), possibly associated with individual grain boundaries. Such a detailed investigation is the focus of future work. Figure 20 again highlights that corrosion damage appears unrelated to cathodic particles, which can be summarily defined as stochastic in its nature.

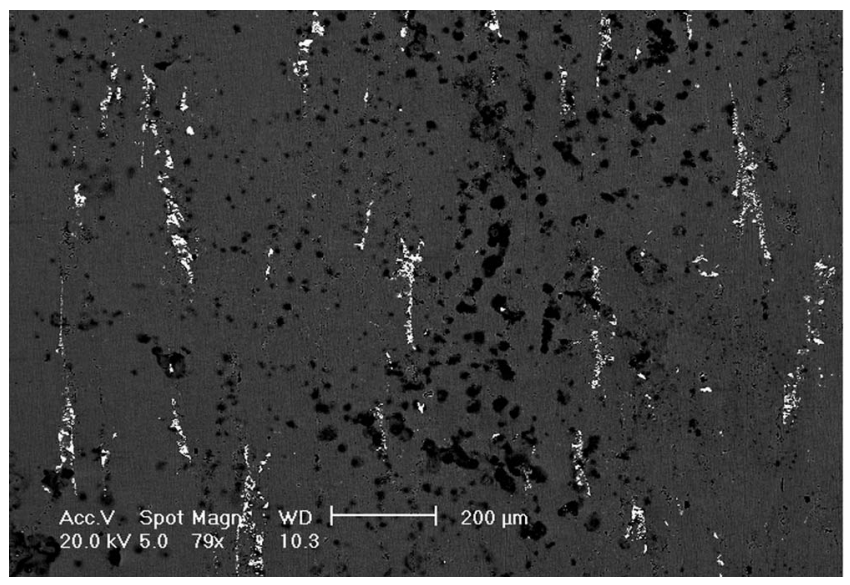

Figure 19. SEM image of AA7075-T651 exposed in $0.1 \mathrm{M} \mathrm{NaCl}$ at $\mathrm{pH} 2.5$ for $24 \mathrm{~h}$. Electron detector used was an equal mix of secondary and backscattered electrons. 


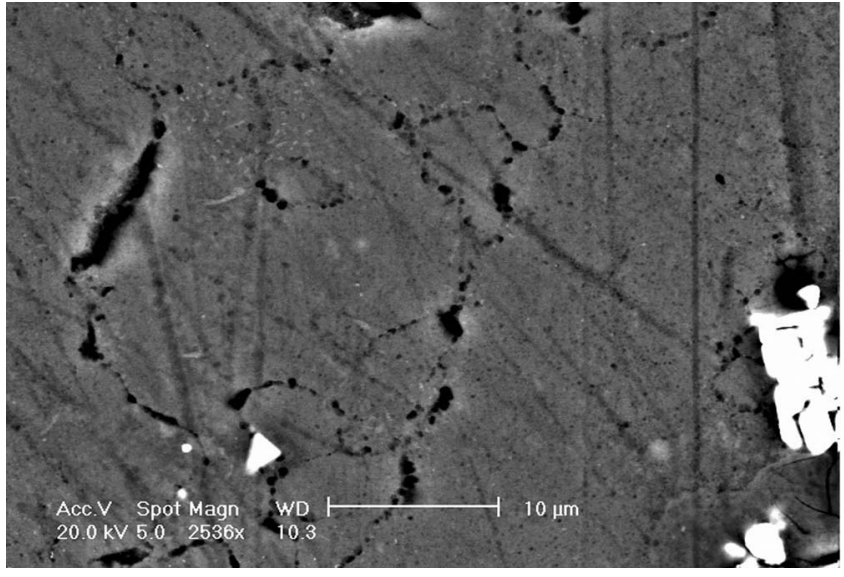

Figure 20. Higher magnification SEM image of AA7075-T651 exposed in $0.1 \mathrm{M} \mathrm{NaCl}$ at $\mathrm{pH} 2.5$ for $24 \mathrm{~h}$ (secondary electron image).

For the case of exposure to an alkaline solution $(0.1 \mathrm{M} \mathrm{NaCl}$ at $\mathrm{pH}$ 12.5), the associated damage is seen in Fig. 21. The exposure in this case was limited to $5 \mathrm{~h}$ because large-scale corrosion and sample discoloration was evident. It is clear that the damage morphology is markedly different from acid exposure, and indeed neutral $\mathrm{pH}$ exposure. ${ }^{13}$ Again, corrosion is not associated directly with cathodic intermetallics, although such intermetallics can likely function as cathodes nonetheless. Instead, the damage is best described as a large-scale matrix dissolution in a general sense, concomitant with the large currents revealed by the potentiodynamic testing (Fig. 18). This matrix dissolution is clearly evident from Fig. 21, because secondary electrons were used to generate the image such that the light particles represent material that sits "proud" of the (receded) surface. Furthermore, the "mud cracking" on the matrix materials is related to oxide cracking, posited to be associated with a corrosion product several $\mu \mathrm{m}$ in thickness. In fact, this damage phenomenon is so marked that it is visible with the naked eye given the correct illumination.

The somewhat higher resolution images in Fig. 22 emphasize the reconciliation between the microcell results and the observed damage. Figure 22a shows a secondary electron image such that intermetallic particles appear proud of the surface; however, the associated backscattered electron image reveals an interesting result. Particle A, which was seen to be unaffected in Fig. 22a, appears dark on the basis of the compositional contrast offered by the backscattered electron imaging. Subsequent EDXS reveals the presence of

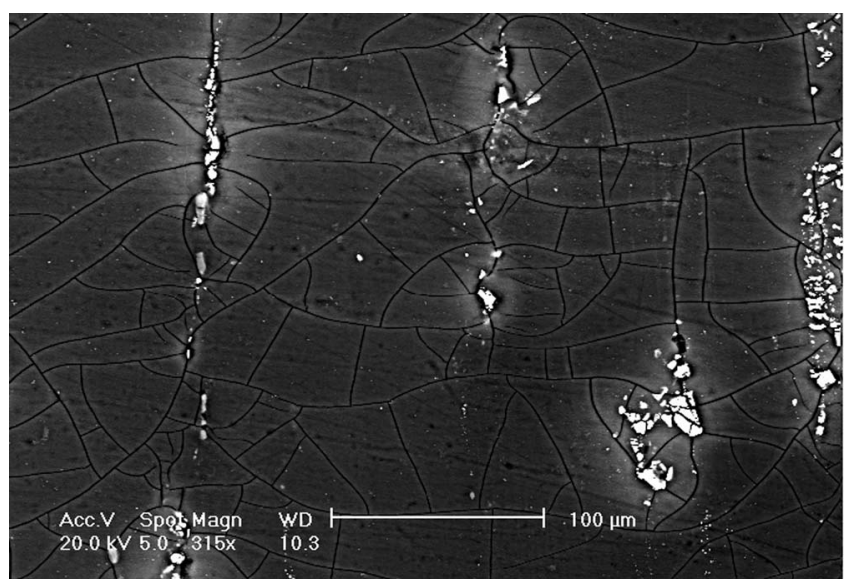

Figure 21. SEM image of AA7075-T651 exposed in $0.1 \mathrm{M} \mathrm{NaCl}$ at $\mathrm{pH} 12.5$ for $5 \mathrm{~h}$ (secondary electron image). abundant $\mathrm{Mg}$ and $\mathrm{Si}$ as seen in Fig. 22c, whereas the stringer particle reveals the presence of $\mathrm{Cu}$ and $\mathrm{Fe}$, Fig. 22d. Based on prior alloy stereology work, we believe these particles to be $\mathrm{Mg}_{2} \mathrm{Si}$ and $\mathrm{Al}_{7} \mathrm{Cu}_{2} \mathrm{Fe} .{ }^{13}$ This therefore confirms that $\mathrm{Al}_{7} \mathrm{Cu}_{2} \mathrm{Fe}$-type particles and indeed the $\mathrm{Mg}_{2} \mathrm{Si}$ intermetallic are unattacked at an elevated $\mathrm{pH}$, as predicted from the microcell testing. The physical response of both $\mathrm{Al}_{2} \mathrm{CuMg}$ and $\mathrm{Al}_{2} \mathrm{Cu}$ was not determined from the exposure of AA7075-T651 because these compounds appear in a low number density in such an alloy, and are often difficult to resolve when corrosion has occurred. ${ }^{13}$

General discussion.- Overall, the work herein extends beyond the somewhat first-order notion that the corrosion of such alloys is simply related to the microstructure, indicating that the relationship is especially complex and heavily dependent on the environment and the level of corrosion being experienced, because the latter can also influence the microenvironment in the vicinity of anodic or cathodic activity upon the metal surface. The incorporation of such a complexity is critical in the prediction of corrosion, such that any predictive models do not under- or overpredict corrosion damage based upon an incorrect assessment or lack of sensitivity of corrosion upon the environment. In the case of aircraft, the corrosive environment will alter significantly, both as electrolytes become concentrated or diluted, and as corrosion proceeds. We explored the physical aspects of the fundamental microcell data via the extreme conditions of bulk alloy exposure in highly acidic and highly alkaline bulk environments as two model examples. Although such conditions may not be encountered in general service, the testing highlights the $\mathrm{pH}$-dependent response of intermetallic particles, along with the bulk alloy, and conditions that could be seen locally in a corroding specimen. It is seen rather clearly that the mode of corrosion upon AA7075-T651 is stochastic at acid pH, general at alkaline $\mathrm{pH}$, and largely deterministic, based heavily on the stereology (i.e., microstructure) and electrochemistry of intermetallics, at a nearneutral $\mathrm{pH}$. This has vast consequences in the development of predictive models for localized damage accumulation, highlighting the notion that the environment is as critical as the microstructure in terms of corrosion, and that the ultimate damage represents the intersection of the two. This also indicates heavily that the correct interpretation of the corrosion of such alloys must be sensitive to the environment; hence, qualitative indices such as the Volta potential ${ }^{30}$ are of limited use for such complex systems because the Volta potential is a qualitative value measured in air; which has no relevance to what may occur in say, as an example, alkaline $\mathrm{pH}$. Another critical factor that represents work in progress is the electrochemical characteristics as a function of temperature.

\section{Conclusions}

The information provided herein is a useful resource for clarification pertaining to the electrochemical behavior of $\mathrm{Al}$ alloys, drawing together a large amount of characteristic data in standard test solutions to allow for a consolidated presentation. It is seen that the electrochemical response of intermetallics that populate high strength $\mathrm{Al}$ alloys, tested herein, is heavily dependent on the $\mathrm{pH}$ of the environment, and significantly more complex than the relative activity or nobility that may be guessed from the composition or corrosion potential, while thermodynamics may not be a satisfactory index of kinetics. A detailed treatise of this was not presented on theoretical grounds; however, empirical data reported clearly reveal this to be the case. A simple example of this is that, in cases where $\mathrm{Mg}_{2} \mathrm{Si}$ reveals its noblest potential (in acid $\mathrm{pH}$ ), it also displays its highest dissolution rates.

Some highlights include the finding that the intermetallics containing $\mathrm{Fe}$ increase their cathodic efficiency as the $\mathrm{pH}$ increased to more alkaline values. This can have attendant ramifications in the damage evolution upon bulk alloys in near-neutral conditions, and indicates both that large amounts of corrosion ought to be synonymous with such particles, while any corrosion protection mechanism should also be likely aimed at incorporating a mechanism for halting 


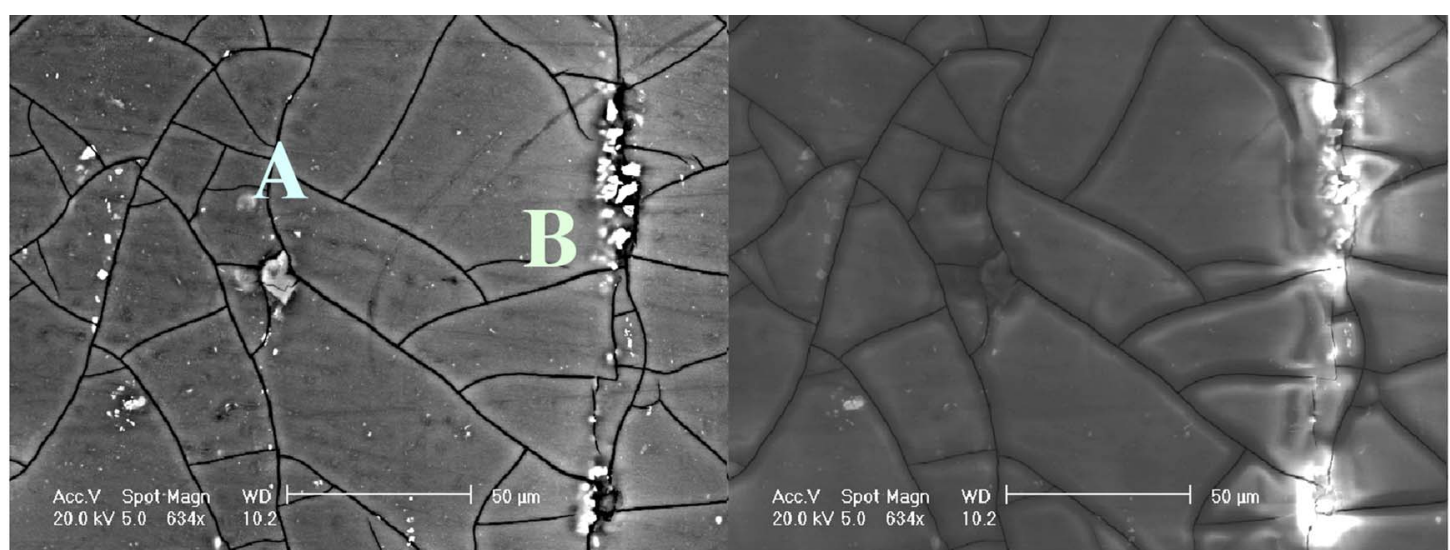

(a)

(b)

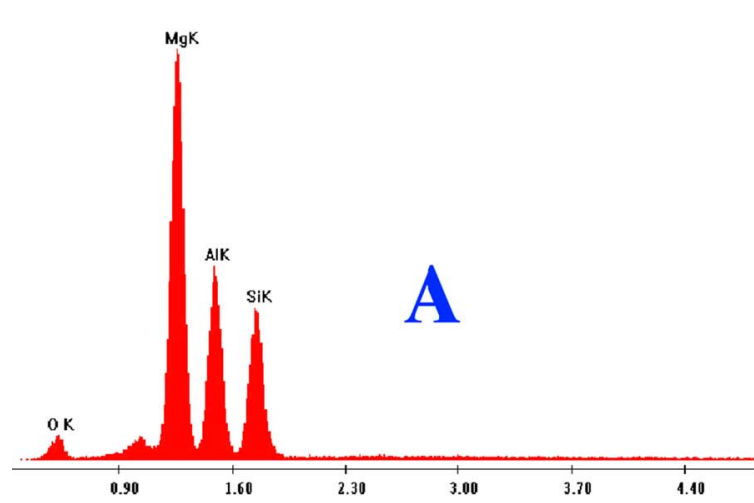

(c)

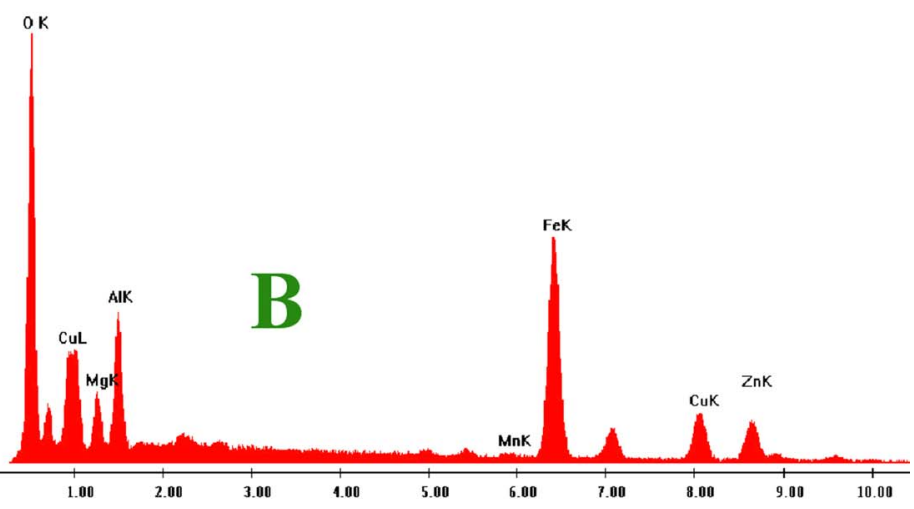

(d)

Figure 22. (Color online) Higher magnification SEM image of AA7075-T651 exposed in $0.1 \mathrm{M} \mathrm{NaCl}$ at pH 12.5 for 5 h. (a) Secondary electron image. (b) Backscattered electron image. (c) EDXS spectrum of particle A, revealing Mg and Si along with matrix background. (d) EDXS spectrum of particle B, revealing $\mathrm{Fe}$ and $\mathrm{Cu}$ along with matrix background.

such cathodic activity. It was also seen that $\mathrm{Mg}_{2} \mathrm{Si}$, nominally spontaneously active, was capable of displaying active-passive behavior at $\mathrm{pH} 12.5$, suggesting that its electrochemical response is dominated by $\mathrm{Mg}$, allowing the formation of a stable oxide film at an alkaline $\mathrm{pH}$.

Investigation of the morphology of corrosion following exposure to acid and alkaline environments for AA7075-T651 reconciles the fundamental microcell data and highlights the highly pH-specific damage evolution modes, and attendant morphology, that occur in $\mathrm{Al}$ alloys. This allows us to now interpret corrosion damage in a far more detailed, quantitative, and meaningful manner.

The Ohio State University assisted in meeting the publication costs of this article.

\section{References}

1. N. Birbilis and R. G. Buchheit, J. Electrochem. Soc., 152, B140 (2005).

2. G. O. Ilevbare, O. Schneider, R. G. Kelly, and J. R. Scully, J. Electrochem. Soc., 151, B453 (2004).

3. M. Büchler, T. Watari, and W. H. Smyrl, Corros. Sci., 42, 1661 (2000).

4. M. Pourbaix, Atlas of Electrochemical Equilibria in Aqueous Solutions, NACE, TX (1974).

5. O. Schneider, G. O. Ilevbare, R. G. Kelly, and J. R. Scully, J. Electrochem. Soc., 151, B465 (2004).

6. G. O. Ilevbare and J. R. Scully, J. Electrochem. Soc., 148, B196 (2001).

7. J. R. Scully, T. O. Knight, R. G. Buchheit, and D. E. Peebles, Corros. Sci., 35, 185 (1993).
8. R. G. Buchheit, J. Electrochem. Soc., 142, 3994 (1995).

9. R. P. Wei, C.-M. Liao, and M. Gao, Metall. Mater. Trans. A, 29, 1153 (1998).

10. P. Leblanc and G. S. Frankel, J. Electrochem. Soc., 149, B239 (2002).

11. I. J. Polmear, Light Alloys, 3rd ed., Arnold, London (1995).

12. Q. Meng and G. S. Frankel, J. Electrochem. Soc., 151, B271 (2004).

13. N. Birbilis, M. K. Cavanaugh, R. G. Buchheit, D. G. Harlow, and R. P. Wei, in Proceedings of Symposium: Application of Materials Science to Military Systems, Materials Science and Technology '05, Pittsburgh, PA, TMS (2005).

14. L. F. Mondolfo, The Aluminum-Magnesium-Zinc Alloys, Research and Development Center, Revere Copper and Brass Inc., Rome, NY (1967).

15. J. O. Park, C. H. Paik, Y. H. Huang, and R. C. Alkire, J. Electrochem. Soc., 146, 517 (1999)

16. T. Suter and H. Böhni, Electrochim. Acta, 43, 2843 (1998).

17. M. M. Lohrengel, Corros. Eng., Sci. Tech., 39, 53 (2004).

18. T. Suter and R. C. Alkire, J. Electrochem. Soc., 148, B36 (2001).

19. N. Birbilis, B. N. Padgett, and R. G. Buchheit, Electrochim. Acta, 50, 3536 (2005).

20. R. M. Leard, M.Sc. Thesis, The Ohio State University, Columbus, OH (2001).

21. R. G. Buchheit, M. A. Martinez, and L. P. Montes, J. Electrochem. Soc., 147, 119 (2000).

22. T. J. R. Leclère and R. C. Newman, J. Electrochem. Soc., 149, B52 (2002).

23. Z. Szklarska-Smialowska, Corros. Sci., 41, 1743 (1999),

24. C. M. Liao, J. M. Olive, M. Gao, and R. P. Wei, Corrosion (Houston), 54, 451 (1998).

25. P. K. Poulose, J. E. Morral, and J. McEvily, Metall. Trans., 5, 1393 (1974).

26. J. A. Wert, Scr. Metall., 15, 445 (1981).

27. S. Jain, Ph.D. Thesis, The Ohio State University, Columbus, OH (2006).

28. R. G. Buchheit, R. P. Grant, P. F. Hlava, B. McKenzie, and G. L. Zender, J. Electrochem. Soc., 144, 2621 (1997).

29. N. Birbilis, M.K. Cavanaugh, and R.G. Buchheit, ECS Trans., 1(4), 115 (2006).

30. J. H. W. de Wit, Electrochim. Acta, 49, 2841 (2004). 